\title{
Heat Production Partition in Sheep Fed above Maintenance from Indirect Calorimetry Data
}

\author{
Patricia Criscioni1 ${ }^{1}$ María del Carmen López ${ }^{1}$, Victor Zena ${ }^{2}$, Carlos Fernández ${ }^{{ }^{*}}$ \\ ${ }^{1}$ Research Center ACUMA, Animal Science Department, Polytechnic University of Valencia, Valencia, Spain \\ ${ }^{2}$ Interuniversity Institute of Bioengineering Research and Technology Oriented to the Human Being, \\ Universidad Politécnica de Valencia, Valencia, Spain \\ Email: ${ }^{*}$ cjfernandez@dca.upv.es
}

Received 11 February 2015; accepted 23 March 2015; published 27 March 2015

Copyright (C) 2015 by authors and Scientific Research Publishing Inc.

This work is licensed under the Creative Commons Attribution International License (CC BY). http://creativecommons.org/licenses/by/4.0/

(c) (i) Open Access

\section{Abstract}

The objective of this study is to compare the partition of heat energy (HE) in two sheep breeds by indirect calorimetry and integral calculus. An experiment was conducted with two Spanish native sheep breeds (dry and non-pregnant) which were fed with pelleted mixed diets above maintenance. Six Guirras and six Manchegas breed sheep were selected (58.8 \pm 3.1 and $60.2 \pm 3.2 \mathrm{~kg}$ body weight, respectively). All sheep were fed with the same concentrate mixed ration $(0.300 \mathrm{~kg}$ cereal straw as forage and $0.700 \mathrm{~kg}$ concentrate) in two meals. Half the daily ration was offered at $800 \mathrm{~h}$ and another half at $1600 \mathrm{~h}$. The sheep had free access to water. Sheep were allocated in metabolic cages; energy balance and gas exchange were assessed in each sheep. The statistical analyses included the fixed effect of breed and random effect of sheep. The metabolic energy (ME) for maintenance represented $69 \%$ of the total ME intake and the average was $354 \mathrm{~kJ}$ per $\mathrm{kg}$ of metabolic body weight $\left(\mathrm{kg}^{0.75} \mathrm{BW}\right)$ on average. The basal metabolism $(\mathrm{HeE})$ was greater $(\mathrm{P}<0.05)$ in Guirra than Manchega breed ( $270 \pm 18$ vs. $247 \pm 15 \mathrm{~kJ} / \mathrm{kg}^{0.75} \mathrm{BW}$ and day). As sheep were fed with above maintenance, the retained energy in the body accounted for $22 \%$ of the ME intake and $77 \%$ of the ME intake was lost as heat. $51 \%$ of the MEI was converted to HeE; $5 \%$ was lost as physical activity of standing and lying down $(\mathrm{HjE})$, and $13 \%$ was associated with the process of feeding and work of digestion and metabolism (HdE). Within $\mathrm{HdE}, 47 \%$ represented the cost of intake and feeding and $\mathbf{5 4 \%}$ the cost of digestion and metabolism. No differences in HE partition between breeds were found, although Guirra breed showed less efficiency of energy retention than Manchega breed. Therefore, this study demonstrated a tentative approach of partitioning HE, combining indirect calorimetry and integral calculus.

\footnotetext{
${ }^{*}$ Corresponding author.
} 


\section{Keywords}

\section{Sheep, Heat Production Partition}

\section{Introduction}

In the last few decades a great number of efforts have been devoted to measuring energy expenditure in animals. Animals produce heat from a variety of metabolic processes such as maintenance, thermoregulation, physical activity and production (e.g. deposition of body tissue, and milk production). Indirect calorimetry has played an important role in measuring this energy released as heat or heat production (HE). In open circuit respiration chambers, heat production can be calculated based on the measurements of $\mathrm{O}_{2}$ consumption and $\mathrm{CO}_{2}$ production. The direct measurement of $\mathrm{HE}$ by indirect calorimetry offers the opportunity to evaluate variations among animals in line with their genotype, phenotype or environmental conditions. Heat energy can be further partitioned into that associated with basal metabolism, voluntary activity, product formation, digestion and absorption, thermal regulation, heat of fermentation, and waste formation and excretion. Partition of HE into meaningful physiological or metabolic components is the most difficult and controversial aspect of all feeding systems [1]. The calculation of heat increment in producing animals needs the partitioning of total HE between a component due to maintenance and a component due to production. The fasting heat production (FHP) post feeding depends on the previous feeding level, and length of fasting, and often includes a contribution of physical activity. Therefore, activity related total HE is the most variable component of total energy expenditure [2].

Calorimetric techniques can provide direct access to total HE, and experimental interventions and computational techniques are required to disentangle its components [3].

The objective of this study is to present the methodology developed in our laboratory to monitor total HE and the heat increment associated with feeding in two sheep breeds by employing indirect calorimetry and mathematical calculus.

\section{Material and Methods}

\subsection{Animals and Feeding.}

The experimental procedure was approved by the Animal Use and Care Committee of the Polytechnic University of Valencia (Spain) and followed the codes of practice for animals used in experimental works proposed by the European Union [4].

Twelve multiparous, dry and non-pregnant sheep of two Spanish native breeds were used in this experiment. Guirra breed belong to Valencia Province and Manchega breed to Castilla-La Mancha Province (Spain), both are autochthonous breeds and almost no information about energy partitioning is available from these breeds. Energy metabolism information would be useful for energy requirements purposes. Six Guirras and six Manchegas breed sheep were selected, which had similar body weight (58.8 \pm 3.1 and $60.2 \pm 3.2 \mathrm{~kg}$ of BW, respectively). It is a mature weight for Guirra [5] and almost for Manchega [6]; mature weight in females Guirra and Manchega ranged between $50-60$ and $65-75 \mathrm{~kg}$, respectively. The experiment was conducted as a random design with the two breeds as fixed effect. All sheep were fed the same concentrate mixed ration $(0.300 \mathrm{~kg}$ cereal straw as forage and $0.700 \mathrm{~kg}$ concentrate) in two meals. Half the daily ration was offered at $800 \mathrm{~h}$ and half at $1600 \mathrm{~h}$, respectively. Sheep had free access to water. The concentrate was mixed and pelleted along with the premix. Its chemical composition values on dry matter $(\mathrm{DM})$ basis was $92.62 \%$ organic matter $(\mathrm{OM}), 17.19 \%$ crude protein $(\mathrm{CP})$, $47.33 \%$ neutral detergent fiber (NDF), $25.37 \%$ acid detergent fiber (ADF), $8.45 \%$ starch and $18.94 \mathrm{MJ}$ of gross energy (GE) per kg DM, following the recommendation of [7] for sheep. Chemical composition of cereal straw was: $91.30 \% \mathrm{OM}, 4.21 \% \mathrm{CP}, 77.54 \% \mathrm{NDF}, 50.33 \% \mathrm{ADF}$ and $0.91 \%$ of starch.

\subsection{Experimental Schedule and Measurements}

Sheep were fed with experimental diets in pens for 10 days. Once adapted to the diet, the sheep were allocated in metabolic crates for 10 more days, in thermoneutral conditions $\left(20^{\circ} \mathrm{C}\right.$ to $23^{\circ} \mathrm{C}$ as determined by a Hobo probe, ONSET data loggers, Cape Cod, MA, USA). Feed intake, refusals, urine and faeces were collected, weighed and 
recorded daily for each sheep over a collection period of 5 days. Faeces were collected in wire-screen baskets placed under the floor of the metabolic crates and urine was collected through a funnel into plastic buckets containing 100 mlsulphuric acidto maintain a pH below 3 for later analysis. Samples of forage and concentrate, refusals, faeces and urine were stored at $-20^{\circ} \mathrm{C}$, and then pooled for chemical analysis. Ruminal fluid samples were collected by stomach tube before the morning feeding on the last day of the sample collection period. Ruminal fluid $\mathrm{pH}$ was immediately determined using a Model 265A portable $\mathrm{pH}$ meter (Orion Research Inc., Beverly, MA, USA). A ruminal fluid sample was acidified with $\mathrm{H}_{2} \mathrm{SO}_{4}$ and frozen until later determination of ammonia nitrogen (ammonia-N). Samples for analysis of volatile fatty acids (VFA) were mixed with $\mathrm{H}_{3} \mathrm{PO}_{4}$ and kept frozen until analysis.

The body weight of each animal was taken at the beginning of the diet adaptation period and at the end of the recollection period.

Gaseous exchange was measured for each ewe during $24 \mathrm{~h}$ ( 6 sheep per breed, one animal per day) using a mobile open-circuit respirometry system (head-hood) designed for small ruminants. As half the daily ration was offered at $800 \mathrm{~h}$ and half at $1600 \mathrm{~h}$, twice a day the head hood drawer was opened, leaving the food and a bucket of water inside. In order to measure fasting, three sheep per breed were randomly selected, and deprived of food for 3 days and the gaseous exchange measurement was done on day 4.

The respirometry system has a head hood, a flow meter (Thermal Mass Flowmeter Sensyflow VT-S, ABB, Alzenau, Germany) and air suction provided by a centrifugal fan (CST60 Soler Palau Inc., Parets del Vallès, Barcelona, Spain). The methane $\left(\mathrm{CH}_{4}\right)$ and carbon dioxide $\left(\mathrm{CO}_{2}\right)$ concentration were measured using the infrared principle and oxygen $\left(\mathrm{O}_{2}\right)$ was measured by the paramagnetic principle (Easyflow Gas Analyzer, model 3020, ABB, Alzenau, Germany). Although the unit was an autocalibrated model, the analysers were calibrated with reference gases before each test. Fernández et al. [8] described the mobile open-circuit respirometry system used and the differences now are that we use a head hood instead of a facemask and, the gas exchange data acquisition is continuous. We described it briefly: The system was capable to record data at intervals of 1 second. Gas analyzer unit and flow meter was connected to the computer (Fujitsu Siemens Lifebook Series, Pentium 4 laptop, Munich, Germany) by an universal serial bus (USB) connector. A serial communication protocol was used with its programmable logic controllers (MODBUS Organization, Inc., Hopkinton, MA, USA; www.modbus.org) for communication between the analytical devices (analyser unit and flow meter) and the computer. The electronics prototyping platform Arduino (www.arduino.cc) was used to send data from the gas analyser unit to LabVIEW7.1 (National Instruments, Austin, Texas, USA) by RS-232 protocol in real time. The flow meter was monitored by a 10 bitanalog to digital converter (model DS2438; Maxim Integrated Products, Inc. Sunnyvale, CA, USA).

The whole system was calibrated injecting pure $\mathrm{N}_{2}$ into the head box [9], determined gravimetrically using a precision scale. Calibration factors were calculated according to [10]. The $\mathrm{CH}_{4}$ and $\mathrm{CO}_{2}$ production and $\mathrm{O}_{2}$ consumption were calculated as described by [11]. An initial atmospheric air sample was collected and the gas concentrations were used as reference for calculations.

\subsection{Chemical Analysis}

Feed, feed refusal and feces samples were first dried in a forced air oven at $55^{\circ} \mathrm{C}$ for $48 \mathrm{~h}$ then ground to pass a 1 $\mathrm{mm}$ screen before analysis. Urine was dried by lyophilization. Chemical analyses of the diet, refusals and feces were conducted according to methods of [12] for DM and ash. DM of diets and feces was determined by ovendrying at $102^{\circ} \mathrm{C} \pm 2^{\circ} \mathrm{C}$ for $24 \mathrm{~h}$. Ash concentration was measured by incineration in an electric muffle furnace at $550^{\circ} \mathrm{C}$ for $6 \mathrm{~h}$ to determine OM. The NDF and ADF were measured in an ANKOM Fiber Analyzer (A220, ANKOM Technologies, Fairport, NY, USA) according to [13] and [12], respectively. NDF was determined using sodium sulfite and alpha amylase. Starch content was determined by enzymatic method ( $\alpha$-amylase obtained from Sigma-Aldrich, Steinheim, Germany) according to [14]. The nitrogen (N) from feed, feces and urine were analysed by the Dumas principle (TruSpec CN; LECO Corporation, St. Joseph, MI, USA). Multiplying N by a factor of 6.25 converted the results to CP. The GE content of the dried samples (feed, feces and urine) was analyzed by combustion in an adiabatic bomb calorimeter (Gallenkamp Autobomb; Loughborough, UK).

$\mathrm{NH}_{3}-\mathrm{N}$ content of ruminal fluid samples was analyzed by the Kjeldahl procedure ( $2300 \mathrm{Kjeltec}$ Analyzer Unit Foss Tecator, Hillerød, Denmark). Determination of ruminal VFA was based on the method described by [15] using a gas chromatograph (Fisons 8000 series; Fisons Instruments SpA, Milan, Italy) equipped with a split/ splitless injector and flame ionization detector. 


\subsection{Calculations}

Themetabolizable energy intake (MEI) was calculated as the difference between gross energy intake (GEI) and energy losses in feces, urine and $\mathrm{CH}_{4}$ (with an energy equivalent value of $39.5 \mathrm{~kJ} / \mathrm{L} \mathrm{CH}_{4}$ [16].

The $\mathrm{HE}$ was determined from measurements of $\mathrm{O}_{2}$ consumption, $\mathrm{CO}_{2}$ and $\mathrm{CH}_{4}$ production, and urine $\mathrm{N}$ (Nur), using the equation [16]:

$$
\mathrm{HE}(\mathrm{kJ})=16.18 \times \mathrm{O}_{2}+5.02 \times \mathrm{CO}_{2}-2.17 \times \mathrm{CH}_{4}-5.99 \times \mathrm{Nur}
$$

where gases were expressed in liters per hours and Nur in grams per day. The body tissue energy $\left(\mathrm{RE}_{\mathrm{body}}\right)$ was calculated as MEI - HE.

The energy associated with the oxidation of protein (OXP), carbohydrate (OXCHO) and fat (OXF) was calculated by the method of [17] and [18] for ruminants. The production of volatile fatty acid from carbohydrate fermentation is followed by $\mathrm{CO}_{2}$ and $\mathrm{CH}_{4}$ production. A ratio $\mathrm{CO}_{2}: \mathrm{CH}_{4}$ of 3:1 and 1.7:1 for high grain and high forage diets, respectively [19]. The $\mathrm{CO}_{2}$ production from oxidation $\left(\mathrm{CO}_{2} \mathrm{x}\right)$ was calculated as $\mathrm{CO}_{2}-\left(\mathrm{CO}_{2}: \mathrm{CH}_{4} \times\right.$ $\mathrm{CH}_{4}$ ). The calculations were carried as following:

OXP $=6.25 \times \mathrm{Nur} \times 18.42(\mathrm{~kJ} / \mathrm{g})$,

$\mathrm{OXCHO}=\left(-2.968 \times \mathrm{O}_{2}+4.174 \times \mathrm{CO}_{2} \mathrm{x}-2.446 \times \mathrm{Nur}\right) \times 17.58(\mathrm{~kJ} / \mathrm{g})$,

$\mathrm{OXF}=\left(1.719 \times \mathrm{O}_{2}-1.719 \times \mathrm{CO}_{2} \mathrm{x}-1.963 \times \mathrm{Nur}\right) \times 39.76(\mathrm{~kJ} / \mathrm{g})$.

Then, the HE from oxidation $(\mathrm{HxE})$ was:

$\mathrm{HxE}(\mathrm{kJ})=16.18 \times \mathrm{O}_{2}+5.02 \times \mathrm{CO}_{2} \mathrm{x}-5.99 \times$ Nur.

Gases were expressed in liters perhours and Nur in grams per day. The non protein respiratory quotient from oxidation of nutrients $(\mathrm{RQnpx})$ was determined as: $\mathrm{RQnpx}=\left(\mathrm{CO}_{2 \mathrm{x}}-\left(\mathrm{N}_{\mathrm{ur}} \times 6.25 \times 0.774\right)\right) /\left(\mathrm{O}_{2}-\left(\mathrm{N}_{\mathrm{ur}} \times 6.25 \times\right.\right.$ 0.957).

As we mentioned above, retained or recovered energy was determined as the difference between MEI and the HE. Heat energy associated with $\mathrm{RE}_{\text {body }}(\mathrm{HrE})$ and $\mathrm{ME}$ used for tissue gain (MEr) were based on an assumed efficiency of dietary ME use for tissue gain of 0.75 [20]. Therefore, ME for maintenance (MEm) was estimated by difference between MEI and MEr, and the efficiency of use of ME for maintenance $\left(\mathrm{k}_{\mathrm{m}}\right)$ as basal metabolic rate over MEm. The $\mathrm{N}$ balance ( $\mathrm{N}$ retained) was determined as well, by difference among $\mathrm{N}$ intake and feces plus urine.

\subsection{Heat Production Partition}

The total HE consist of many components: basal metabolism (HeE), heat associated with voluntary activity $(\mathrm{HjE})$, heat of product formation ( $\mathrm{HrE})$, heat for thermal regulation $(\mathrm{HcE})$, heat of synthesis and excretion of waste products (HwE), heat of digestion (HdE) and heat of fermentation (HfE). This energy terms was defined according to [1].

$\mathrm{HE}=\mathrm{HeE}+\mathrm{HjE}+\mathrm{HrE}+\mathrm{HcE}+\mathrm{HwE}+\mathrm{HdE}+\mathrm{HfE}$.

Due to the animals being in a thermoneutral and non-stressful environment, HcE was assumed to be zero. The NRC [1] defines the heat increment of feeding (HiE) as:

$\mathrm{HiE}=\mathrm{HrE}+\mathrm{HdE}+\mathrm{HfE}+\mathrm{HwE}$.

In our trial we considered $\mathrm{HwE}$ negligible and, $\mathrm{HfE}=\mathrm{HE}-\mathrm{HxE}$.

Therefore, the HE was partitioned between components due to feed intake, physical activity, and basal metabolic rate. This partitioning is described as follows.

$\mathrm{HE}=\mathrm{HeE}+\mathrm{HjE}+\mathrm{HiE}$.

The maintenance requirements consist of basal metabolic rate plus the activity increment, and are usually defined as FHP; therefore we define FHP as a sum of two components; HeE and HjE. The HeE corresponded to the minimum energy expenditure of resting, healthy, non-reproductive, fasting and adult animal that are in a thermoneutral environment during the inactive circadian phase [21]. The activity increment was assumed in our study as the difference between FHP and HeE.

$\mathrm{HjE}=\mathrm{FHP}-\mathrm{HeE}$.

The term defined by NRC [1] as heat of digestion (HdE) includes the energy cost of eating, rumination, work of digestion and nutrient metabolism. The HdE was determined as follows:

$\mathrm{HdE}=\mathrm{HE}-\mathrm{HeE}-\mathrm{HrE}-\mathrm{HjE}$.

Then, $\mathrm{HdE}$ was divided in $\mathrm{HE}$ of eating $\left(\mathrm{HdE}_{\mathrm{e}}\right)$ and $\mathrm{HdE}$ of digestion and metabolism $\left(\mathrm{HdE}_{\mathrm{dm}}\right)$. The cost of 
eating is defined in the literature as the act of prehending, biting, chewing, salivating and swallowing throughout a time period (use to be 15 minutes, according to [22] and [2]). In our study the cost of eating $\left(\mathrm{HdE}_{\mathrm{e}}\right)$ is guided by the increase in HE from the moment that feed is offered on the feeder to 3 hours later, and we measure the peak area under the curve. The $\mathrm{HdE}_{\mathrm{dm}}$ was obtained by difference and we assumed included the work of digestion and metabolism. The two HdE components include rumination and must include the energy cost (oxygen consumption) of gastrointestinal and hepatic organs, although each of these activities was not quantifies.

$\mathrm{HdE}=\mathrm{HdE}_{\mathrm{e}}+\mathrm{HdE}_{\mathrm{dm}}$.

Figure 1 shows some nomenclature described above and we can realize that the partition of $\mathrm{HdE}$ in $\mathrm{HdE}_{\mathrm{e}}$ and $\mathrm{HdE}_{\mathrm{dm}}$ is theorical, based on the curve pattern of the metabolic rate (HE).

\subsection{Data Analyses}

The quantification of partitioning HE was developed by integral calculus in R (version 2.12.2, R Foundation for Statistical Computing, Viena, Austria). Duration of gas exchange was fixed at 1 day, and the time unit was minutes.

The integrated areas were:

$\mathrm{HE}=$ The Total Heat Production in fed and fasted animal was determined using integral of curves formed by data from indirect calorimetry.

$\mathrm{HiE}=$ Difference of integrals of HE and FHP.

$\mathrm{FHP}=$ Integral of fasting heat production, divided in $\mathrm{HeE}$ and $\mathrm{HjE}$.

$\mathrm{HjE}=$ Difference of integrals FHP and HeE.

$\mathrm{HeE}$ value was determined as the area under the curve defined by the value repeated more frequently (mode) of the mean values of data obtained from the respirometry of 3 fasting animals, once the highest values were dropped, which could be caused by movements.

$\mathrm{HdE}_{\mathrm{e}}=$ Difference of integrals of total HE and FHP in an approximate 3-hour period after feeding.

$\mathrm{HfE}=$ Is the difference between integrals of HE and HxE.

Definite integral of a signal can be interpreted as the area under the curve. This numeric integration allows us to evaluate the defined integral of a continuous function in a closed interval with the desired accuracy, and it consists in the adjustment of a polynomial to a set of points and then integrating them.

The integral of each curve was based on the trapezium method. The sum of these areas of trapeziums can be approximated to the integral that represents the area under the curve, according to the following equation:

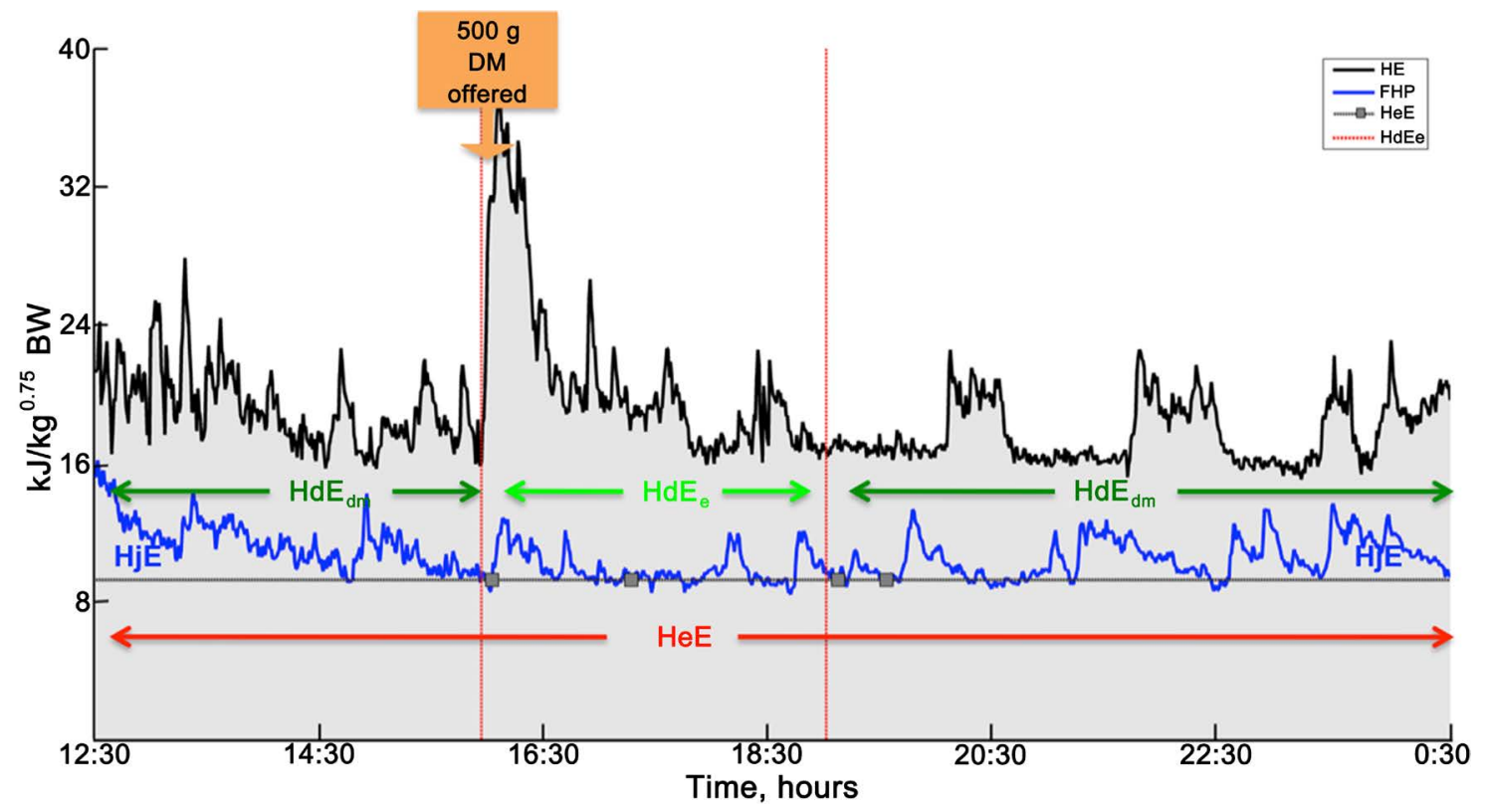

Figure 1. Example of heat production (HE) partitioning and their components: fasting heat production (FHP), basal metabolism $(\mathrm{HeE})$, heat associated with voluntary activity $(\mathrm{HjE})$, heat of digestion $(\mathrm{HdE})$, heat of feeding during 3 hours $\left(\mathrm{HdE}_{\mathrm{e}}\right)$, heat after 3 hours of feeding to next intake $\left(\mathrm{HdE}_{\mathrm{dm}}\right) . \mathrm{FHP}=\mathrm{HeE}+\mathrm{HjE} ; \mathrm{HdE}=\mathrm{HdE}_{\mathrm{e}}+\mathrm{HdE}_{\mathrm{dm}}$. 


$$
S_{\alpha}=\sum_{i=h_{1}}^{h_{n}} x \alpha_{i} \cdot \Delta t \alpha_{i}
$$

where $S_{\alpha}$ represent the area of temporal series $x \alpha_{i}$ to intervals $\Delta t \alpha_{i}$ of one minute to increase during 24 hours corresponding to the animal $\alpha$. In this study the $S_{\alpha}$ and $x \alpha_{i}$ values can be replaced by the descriptions in Table 1.

The effects of breed on heat partition were analyzed using the PROC MIXED of [23]. The experiment was conducted in a randomized design and the model for the dependent variables included the fixed effect of breed and random effect of sheep. The following statistical model was used: $\mathrm{Y}=\mu+\alpha(\mathrm{B})+$ sheep $+\varepsilon$ where $\mathrm{Y}$ is the dependent variable, $\mu$ is the overall mean, B is the breed (Manchega and Guirra), sheep is random effect and $\varepsilon$ is the random error. Effects were declared significant at $\mathrm{P}<0.05$ and $\mathrm{P}$-values between 0.05 and 0.10 were considered as a trend. Student's $t$ test was used for comparison between breeds.

\section{Results}

The data on energy intake and outputs of the sheep, recording during the calorimetric measurement, are presented in Table 2. No significant difference was observed for the energy balance between breeds.

HE partitioning are shown in Table 3. The fasting metabolism in sheep was measured at day 4 after three days of starvation, when respiration quotient has usually fallen to about 0.70 [24]. No differences were observed for FHP between breeds ( $258 \mathrm{~kJ} / \mathrm{kg}^{0.75} \mathrm{BW}$ and day, on average). The basal metabolism (HeE) was significantly $(\mathrm{P}<0.05)$ higher for Guirra than Manchega breed $\left(270\right.$ vs. $247 \mathrm{~kJ} / \mathrm{kg}^{0.75} \mathrm{BW}$ and day, respectively) and no differences for activity were found $\left(27 \mathrm{~kJ} / \mathrm{kg}^{0.75} \mathrm{BW}\right.$ and day).

\section{Table 1. Definition of the areas and temporal series used in the numerical integration.}

\begin{tabular}{ccc}
\hline \multicolumn{1}{c}{$S_{\alpha}$} & $x \alpha_{i}$ & $\mathrm{~h}_{\mathrm{n}}-\mathrm{h}_{1}$ \\
\hline HE (total heat production) & $\mathrm{He} \alpha_{i}$ (heat production per hour) & 24 hours \\
FHP (fasting heat production) & $\mathrm{fhp} \alpha_{i}$ (heat production per hour) & 24 hours \\
HiE (heat increment) & $\mathrm{hiE} \alpha_{i}$ (heat increment per hour) & 24 hours \\
$\mathrm{HdE}_{\mathrm{e}}$ (Heat increment post ingestion) & $\mathrm{hdE} \mathrm{g} \alpha_{i}$ (heat increment per hour) & Approx. 3 hours \\
HfE (heat of fermentation) & $\mathrm{hfE} \alpha_{i}$ (heat increment per hour) & 24 hours \\
\hline
\end{tabular}

Table 2. Dry matter intake $(\mathrm{g} / \mathrm{d})$ and energy balance $\left(\mathrm{kJ} / \mathrm{kg}^{0.75} \mathrm{BW}\right)$ in two sheep breeds.

\begin{tabular}{|c|c|c|c|c|}
\hline & \multicolumn{2}{|c|}{ Breeds } & \multirow{2}{*}{ SEM $^{1}$} & \multirow{2}{*}{ P-value } \\
\hline & Guirras & Manchegas & & \\
\hline $\mathrm{LW}^{2}, \mathrm{~kg}$ & 58.0 & 60.2 & 1.16 & 0.981 \\
\hline $\mathrm{DMI}^{3}, \mathrm{~g} / \mathrm{d}$ & 883.3 & 984.8 & 45.23 & 0.287 \\
\hline \multicolumn{5}{|c|}{ Energy balance, $\mathrm{kJ} / \mathrm{kg}^{0.75} \mathrm{BW}$} \\
\hline $\mathrm{GEI}^{4}$ & 803 & 854 & 25.3 & 0.34 \\
\hline$E^{5}$ feces & 226 & 260 & 28.8 & 0.56 \\
\hline E urine & 41 & 29 & 5.5 & 0.31 \\
\hline E methane & 50 & 46 & 3.5 & 0.66 \\
\hline $\mathrm{ME}^{6}$ & 487 & 518 & 13.4 & 0.260 \\
\hline $\mathrm{RE}_{\text {body }}^{7}$ & 99 & 124 & 14.1 & 0.42 \\
\hline $\mathrm{RE}_{\text {protein }}$ & 48 & 70 & 7.4 & 0.11 \\
\hline $\mathrm{RE}_{\text {fat }}$ & 52 & 54 & 12.6 & 0.98 \\
\hline ME gain & 132 & 165 & 18.8 & 0.42 \\
\hline ME maintenance & 354 & 353 & 8.3 & 0.95 \\
\hline $\mathrm{km}^{8}$ & 0.77 & 0.70 & 0.021 & 0.099 \\
\hline
\end{tabular}

${ }^{1} \mathrm{SEM}=$ standard error of the mean; ${ }^{2} \mathrm{BW}=$ body weight $;{ }^{3} \mathrm{DMI}=$ dry matter intake; ${ }^{4} \mathrm{GEI}=$ gross energy intake; ${ }^{5} \mathrm{E}=\mathrm{energy} ;{ }^{6} \mathrm{ME}=$ metabolizable energy intake; ${ }^{7} \mathrm{RE}=$ retained energy; ${ }^{8} \mathrm{~km}=$ efficiency of $\mathrm{ME}$. 
Table 3. HE partitioning $\left(\mathrm{kJ} / \mathrm{kg}^{0.75} \mathrm{BW}\right)$ and HE partitioning per MEI (\%) in two sheep breeds.

\begin{tabular}{|c|c|c|c|c|}
\hline & \multicolumn{2}{|c|}{ Breeds } & \multirow{2}{*}{ SEM $^{1}$} & \multirow{2}{*}{ P-value } \\
\hline & Guirras & Manchegas & & \\
\hline \multicolumn{5}{|c|}{ HE partitioning, $\mathrm{kJ} / \mathrm{kg}^{0.75} \mathrm{BW}$} \\
\hline $\mathrm{HE}^{2}$ & 387 & 394 & 5.5 & 0.56 \\
\hline $\mathrm{HrE}^{3}$ & 33 & 41 & 4.7 & 0.42 \\
\hline $\mathrm{HeE}^{4}$ & 270 & 247 & 4.0 & 0.02 \\
\hline $\mathrm{HjE}^{5}$ & 23 & 30 & 1.2 & 0.453 \\
\hline $\mathrm{FHP}^{6}$ & 293 & 277 & 2.8 & 0.19 \\
\hline $\mathrm{HdE}^{7}$ & 54 & 71 & 8.8 & 0.39 \\
\hline $\mathrm{HdEe}^{8}$ & 24 & 31 & 5.3 & 0.57 \\
\hline $\mathrm{HdEdm}^{9}$ & 30 & 40 & 5.4 & 0.16 \\
\hline $\mathrm{HiE}^{10}$ & 61 & 77 & 8.7 & 0.40 \\
\hline \multicolumn{5}{|c|}{ HE partitioning per $\mathrm{MEI}^{11}, \%$} \\
\hline $\mathrm{RE}_{\text {body }}^{12} / \mathrm{MEI}$ & 20 & 23 & 2.4 & 0.58 \\
\hline $\mathrm{RE}_{\text {protein }} / \mathrm{MEI}$ & 10 & 14 & 1.3 & 0.12 \\
\hline $\mathrm{RE}_{\mathrm{fat}} / \mathrm{MEI}$ & 11 & 10 & 2.4 & 0.81 \\
\hline HE/MEI & 80 & 77 & 2.4 & 0.58 \\
\hline $\mathrm{HrE} / \mathrm{MEI}$ & 7 & 8 & 0.8 & 0.57 \\
\hline $\mathrm{HeE} / \mathrm{MEI}$ & 56 & 48 & 1.8 & 0.02 \\
\hline HjE/MEI & 5 & 6 & 0.2 & 0.01 \\
\hline FHP/MEI & 60 & 54 & 1.8 & 0.06 \\
\hline HdE/MEI & 11 & 14 & 2.0 & 0.49 \\
\hline $\mathrm{HdE}_{\mathrm{e}} / \mathrm{MEI}$ & 5 & 6 & 1.2 & 0.61 \\
\hline $\mathrm{HdE}_{\mathrm{dm}} / \mathrm{MEI}$ & 5 & 8 & 1.2 & 0.21 \\
\hline $\mathrm{HiE} / \mathrm{MEI}$ & 13 & 15 & 2.0 & 0.52 \\
\hline
\end{tabular}

${ }^{1} \mathrm{SEM}=$ standard error of the mean; ${ }^{2} \mathrm{HE}=$ heat production; ${ }^{3} \mathrm{HrE}=$ heat of product formation; ${ }^{4} \mathrm{HeE}=$ basal metabolism; ${ }^{5} \mathrm{HjE}=$ heat associated with voluntary activity; ${ }^{6} \mathrm{FHP}=$ fasting heat production; ${ }^{7} \mathrm{HdE}=$ heat of digestion; ${ }^{8} \mathrm{HdE}_{\mathrm{e}}=$ heat of eating; ${ }^{9} \mathrm{HdE} \mathrm{dm}_{\mathrm{m}}=$ heat of digestion and metabolism; ${ }^{10} \mathrm{HiE}=$ heat increment of feeding; ${ }^{11} \mathrm{MEI}=$ metabolizable energy intake; ${ }^{12} \mathrm{RE}=$ retained energy.

The variation in HE associated with feeding (HdE) was not significantly different between breeds $(62 \mathrm{~kJ} /$ $\mathrm{kg}^{0.75} \mathrm{BW}$ and day, on average). No significant differences were observed for the two components related to then; eating-chewing-rumination $\left(\mathrm{HdE}_{\mathrm{e}}\right)$ and rumination-digestion-metabolism $\left(\mathrm{HdE}_{\mathrm{dm}}\right)$.

The proportional contribution to HxE due to oxidation of nutrients is shown in Table 4. No differences were observed for HxE and OXF and, differences were found in OXCHO and OXP; lower OXCHO (P $<0.05 ; 75$ vs. $\left.129 \mathrm{~kJ} / \mathrm{kg}^{0.75} \mathrm{BW}\right)$ and higher OXP $\left(\mathrm{P}<0.01 ; 52\right.$ vs. $\left.30 \mathrm{~kJ} / \mathrm{kg}^{0.75} \mathrm{BW}\right)$ in Guirra than in Manchega breed of sheep.

No significant differences were observed in $\mathrm{N}$ balance, only Guirra breed shown greater $(\mathrm{P}<0.05)$ values in urine $\mathrm{N}$ compared with Manchega breed: 0.65 vs. $0.35 \mathrm{~g} / \mathrm{kg}^{0.75} \mathrm{BW}$, respectively (Table 5). Table 6 shows the ruminal parameters like, $\mathrm{pH}$, ammonia-N and VFA. Higher ammonia-N values $(\mathrm{P}<0.05)$ were obtained inGuirra breed compared with Manchega breed (22.8 vs. $17.81 \mathrm{mg} / \mathrm{dL}$, respectively) and numerical lower VFA (P $=0.056)$ in Guirra compared with Manchega (33.49 vs. $37.46 \mathrm{mmol} / \mathrm{L}$ ).

\section{Discussion}

\subsection{HE Partition: Activity}

The HjE estimated in our experiment included only the act of standing and lying down. The average value of $\mathrm{HjE}$, in sheep allocated in metabolic cages was $27 \mathrm{~kJ} / \mathrm{kg}^{0.75} \mathrm{BW}$ and day. This value represents the $8.5 \%$ of the $\mathrm{HeE}$ (expressed on FHP the values is $10 \%$ on average). NRC [25] suggested that energy requirements for activity were $10 \%$ of FHP for stall fed sheep. 
Table 4. Energy ( $\left.\mathrm{kJ} / \mathrm{kg}^{0.75} \mathrm{BW}\right)$ associated with the oxidation of nutrients and their percentage over HxE in two sheep breeds.

\begin{tabular}{|c|c|c|c|c|}
\hline & \multicolumn{2}{|c|}{ Breeds } & \multirow{2}{*}{$\mathrm{SEM}^{1}$} & \multirow{2}{*}{ P-value } \\
\hline & Guirras & Manchegas & & \\
\hline \multicolumn{5}{|c|}{ Oxidation of nutrients, $\left(\mathrm{kJ} / \mathrm{kg}^{0.75} \mathrm{BW}\right)$} \\
\hline $\mathrm{HxE}^{2}$ & 381 & 389 & 5.8 & 0.52 \\
\hline $\mathrm{HfE}^{3}$ & 7 & 6 & 0.7 & 0.65 \\
\hline $\mathrm{OXP}^{4}$ & 52 & 30 & 4.6 & 0.01 \\
\hline $\mathrm{OXCHO}^{5}$ & 72 & 129 & 19.1 & 0.04 \\
\hline $\mathrm{OXF}^{6}$ & 256 & 229 & 16.2 & 0.43 \\
\hline $\mathrm{OXP} / \mathrm{HxE}, \%$ & 14 & 8 & 1.2 & 0.02 \\
\hline $\mathrm{OXCHO} / \mathrm{HxE}, \%$ & 19 & 33 & 5.0 & 0.05 \\
\hline $\mathrm{OXF} / \mathrm{HxE}, \%$ & 68 & 59 & 4.5 & 0.36 \\
\hline RQnpx $^{7}$ & 0.81 & 0.87 & 0.033 & 0.521 \\
\hline $\mathrm{HxE} / \mathrm{MEI}^{8}, \%$ & 78 & 76 & 2.3 & 0.60 \\
\hline HfE/MEI, \% & 1.3 & 1.2 & 0.14 & 0.521 \\
\hline
\end{tabular}

${ }^{1} \mathrm{SEM}=$ standard error of the mean; ${ }^{2} \mathrm{HxE}=$ heat production of oxidation; ${ }^{3} \mathrm{HfE}=$ heat of fermentation; ${ }^{4} \mathrm{OXP}=$ energy associated with the oxidation of protein; ${ }^{5} \mathrm{OXCHO}=$ energy associated with the oxidation of carbohydrate; ${ }^{6} \mathrm{OXF}=$ energy associated with the oxidation of fat; ${ }^{7} \mathrm{RQnpx}=$ non protein respiratory quotient from oxidation of nutrients; ${ }^{8} \mathrm{MEI}=$ metabolizable energy intake.

Table 5. Nitrogen balance $\left(\mathrm{g} / \mathrm{kg}^{0.75} \mathrm{BW}\right)$ in two sheep breeds.

\begin{tabular}{|c|c|c|c|c|}
\hline & \multicolumn{2}{|c|}{ Breeds } & \multirow{2}{*}{$\mathrm{SEM}^{1}$} & \multirow{2}{*}{ P-value } \\
\hline & Guirras & Manchegas & & \\
\hline $\mathrm{N}^{2}$ intake & 1.28 & 1.19 & 0.033 & 0.211 \\
\hline $\mathrm{N}$ feces & 0.30 & 0.35 & 0.031 & 0.429 \\
\hline $\mathrm{N}$ urine & 0.65 & 0.35 & 0.060 & 0.003 \\
\hline $\mathrm{N}$ retained & 0.33 & 0.49 & 0.050 & 0.109 \\
\hline RProtein $^{3}, \mathrm{~g} / \mathrm{d}$ & 43 & 64 & 6.2 & 0.09 \\
\hline $\mathrm{RFat}^{4}, \mathrm{~g} / \mathrm{d}$ & 27 & 29 & 8.1 & 0.58 \\
\hline Gain, g/d & 199 & 285 & 23.3 & 0.12 \\
\hline
\end{tabular}

${ }^{1} \mathrm{SEM}=$ standard error of the mean; ${ }^{2} \mathrm{~N}=$ nitrogen $;{ }^{3} \mathrm{RProtein}=$ retained protein $;{ }^{4} \mathrm{RF}$ at $=$ retained fat.

Table 6. pH, ammonia $\mathrm{N}$ and volatile fatty acids (VFA) in two sheep breeds.

\begin{tabular}{|c|c|c|c|c|}
\hline & \multicolumn{2}{|c|}{ Breeds } & \multirow{2}{*}{ SEM $^{1}$} & \multirow{2}{*}{ P-value } \\
\hline & Guirras & Manchegas & & \\
\hline $\mathrm{pH}$ & 7.30 & 7.22 & 0.172 & 0.652 \\
\hline Ammonia $\mathrm{N}^{2}, \mathrm{mg} / \mathrm{dL}$ & 22.80 & 17.81 & 3.256 & 0.048 \\
\hline Total VFA ${ }^{3}, \mathrm{mmol} / \mathrm{L}$ & 33.49 & 37.46 & 3.276 & 0.056 \\
\hline \multicolumn{5}{|l|}{ VFA, mmol/L } \\
\hline Acetic & 23.47 & 26.43 & 1.552 & 0.081 \\
\hline Propionic & 6.70 & 5.80 & 0.982 & 0.18 \\
\hline Isobutyric & 0.88 & 0.68 & 0.111 & 0.07 \\
\hline Butyric & 3.55 & 3.15 & 0.573 & 0.55 \\
\hline Isovaleric & 1.28 & 0.93 & 0.142 & 0.24 \\
\hline $\mathrm{N}$-valeric & 0.51 & 0.32 & 0.024 & 0.48 \\
\hline N-caproic & 0.07 & 0.09 & 0.003 & 0.35 \\
\hline
\end{tabular}

${ }^{1} \mathrm{SEM}=$ standard error of the mean; ${ }^{2} \mathrm{~N}=$ nitrogen $;{ }^{3} \mathrm{VFA}=$ volatile fatty acids. 
Calorimetric studies have established the following energy cost of various physical activities by ruminants animals [26], and standing compared with lying result in a cost of $10 \mathrm{~kJ} / \mathrm{kg}$ BW and day. In our study we assumed that Manchega made more position changes than Guirra breed (63 compared with 48 position changes, respectively). Goats normally prefer standing while feeding and, in our study more activity (standing up) and more DMI was found in Manchega sheep than Guirra breed (985 vs. 883 g DMI/d, respectively). However, although numerically different, DMI was not significant and considering DMI as percentage of BW, both breeds showed similar DMI (1.6\% BW). If we express HjE per gram of DMI we obtain 0.55 and $0.66 \mathrm{~kJ} \mathrm{HjE} / \mathrm{g}$ DMI for Guirra and Manchega breed, respectively. Therefore, the greater value of physical activity in Manchega breed was not due to numerically higher DMI.

\subsection{HE Partitioning: Feeding}

The HE has been shown to increase during feeding in sheep [22] like in other mammals. Continuous measurements of respiratory exchange consistently show that HE in sheep increases rapidly by $40 \%-80 \%$ during a course of a meal. This increase persisted even through meals lasting up to 2 hours but declines thereafter rapidly to rates not more than $15 \%$ - 20\% greater than those recorded before a meal (Figure 1).

Most of the studies calculated the cost of eating for a short period of time (15 minutes) and the rate of intake was recorded (g DM per minute or bites per minute). This cost is calculated from the increment in HE above the average HE of the pre-feeding period. And it was related to the type and amount of feed consumed and also to the time spent on eating. Our methodology was completely different, with two feeding periods and 24 hours of continuous HE measurement, the measures were based on the greater peak of HE after feeding combined with numerical integration. Therefore our results are not comparable due that we did not record the rate of intake. We found that the cost of intake during 6 hours (two meals) were $28 \mathrm{~kJ} \mathrm{HdE} / \mathrm{kg}^{0.75} \mathrm{BW}$ and day on average, and the cost of digestion and metabolism succeeding 18 hours was $35 \mathrm{~kJ} \mathrm{HdE} \mathrm{dm} / \mathrm{kg}^{0.75} \mathrm{BW}$ and day. The cost of intake with two meals represent the $47 \%$ of the total HdE, while $54 \%$ would be the cost of digestion and metabolism of the sheep on the metabolic cages with almost minimal physical activity. The $\mathrm{HdE}_{\mathrm{e}}$ for two meals account for $6 \%$ of the MEI, while $7 \%$ of the MEI was expended in $\mathrm{HdE}_{\mathrm{dm}}$, and no comparable result was found from the literature (Table 3). The HfE was more related to the cost of methane produced than total cost of fermentation, and due to this reason HfE was determined by difference between $\mathrm{HE}$ and $\mathrm{HxE}$, with values of $7 \mathrm{~kJ} / \mathrm{kg}^{0.75} \mathrm{BW}$, on average (Table 4).

In our study, where sheep were fed above maintenance with mixed diet and concentrate pelleted and, nonlocomotion and thermal stress was considered, the HiE represented $14 \%$ of the MEI. The total energy cost of ingestion and digestion are consistently $40 \%$ to $50 \%$ of HiE for forages but are less for barley pellets; $24 \%$ - $37 \%$ [27].

\subsection{ME for Maintenance}

Feeding level in our trial was estimated as 1.5 times maintenance, hence the sheep was in positive tissue energy balance, and some of the MEI is being directed towards tissue energy gain. The MEm was estimated by difference between MEI and MEr and the value obtained was $354 \mathrm{~kJ} / \mathrm{kg}^{0.75} \mathrm{BW}$ and day on average. The efficiency of use of ME for maintenance was 0.74 on average (slightly higher than NRC [25]), because we have a concomitant energy use for maintenance and gain.

Therefore, next average values were observed (Table 3); the MEm represented the $69 \%$ of the total MEI in this study. As sheep were fed above maintenance, the $\mathrm{RE}_{\text {body }}$ account for $23 \%$ of the MEI and, $77 \%$ of the MEI was lost as heat (HE). Within HE, $51 \%$ of the MEI drove to basal metabolism (HeE), $5.3 \%$ was lost as physical activity of standing and lying down $(\mathrm{HjE})$, and $13 \%$ was associated with the process of feeding and work of digestion and metabolism.

Reviewing the literature, we found variability in determination or estimation of MEm. Manchega sheep had a value of $383 \mathrm{~kJ} / \mathrm{kg}^{0.75} \mathrm{BW}$ in the study [28] and day and [29] [30] in Guirra sheep found a value of $352 \mathrm{~kJ} / \mathrm{kg}^{0.75}$ BW and day and $391 \mathrm{~kJ} / \mathrm{kg}^{0.75} \mathrm{BW}$, respectivelyand an efficiency of use of ME for maintenance of $0.64\left(\mathrm{k}_{\mathrm{m}}\right)$. The estimated MEm requirement in Segureña sheep by linear regression was $374 \mathrm{~kJ} / \mathrm{kg}^{0.75} \mathrm{BW}$ and the efficiency of utilisation of ME for maintenance $\left(\mathrm{k}_{\mathrm{m}}\right)$ was 0.72 [31]. Nine reports [32] suggest MEm ranging from 305 to $460 \mathrm{~kJ} / \mathrm{kg}^{0.75} \mathrm{BW}$, and [33] estimated a MEm for Menz sheep of the Ethiopian highlands $422 \mathrm{~kJ} / \mathrm{kg}^{0.75}$ BW and day. The systems [25] and [34] adopted an average value of 321 and $397 \mathrm{~kJ} / \mathrm{kg}^{0.75} \mathrm{BW}$, respectively due to the fact that FHP $v s$. feeding trial or, calorimetry studies vs. other methods, give different values. Others [35] 
consider values of MEm ranging from 325 to $378 \mathrm{~kJ} / \mathrm{kg}^{0.75} \mathrm{BW}$, and [26] from 286 to $390 \mathrm{~kJ} / \mathrm{kg}^{0.75} \mathrm{BW}$. Thus, the classical definition of maintenance is not described as the state in which there is neither gain nor loss of nutrient by the body [36], in producing animals never occurs. Consequently, the traditional assumption of the constant MEm that is independent of ME intake may be wrong [37].

\subsection{HE Partition: Basal Metabolism}

Higher values for HeE, in Guirra vs. Manchega breed was found ( 270 vs. $247 \mathrm{~kJ} / \mathrm{kg}^{0.75} \mathrm{BW}$ ), indicating metabolic differences between the rustic breed (Guirra) than genetically selected breed (Manchega), where basal metabolic rate was greater [38]. However, no differences were found in FHP. We have to keep in mind that Guirra breed reached mature size in this trial, but Manchega sheep were not getting their mature size yet.

Differences in HeE between breeds are difficult to explain. It could be explicated by the feeding level previous to the experiment, that in our study was the same but, in general, this information is not available in literature. In other studies, the FHP value found in Manchega breed [28] was $268 \mathrm{~kJ} / \mathrm{kg}^{0.75} \mathrm{BW}$ and day, akin to our finding, although sheep were fed with a diet based in alfalfa hay and different amount of barley. Similar values were reported in Segureña sheep breed $\left(272 \mathrm{~kJ} / \mathrm{kg}^{0.75} \mathrm{BW}\right.$ and day) by Aguilera et al. [11], and again the feeding conditions were different; pelleted alfalfa, barley, sunflower meal and olive pulp. However, in the study [29] with Guirra breed with similar BW (57 kg), the FHP was higher $\left(318 \mathrm{~kJ} / \mathrm{kg}^{0.75} \mathrm{BW}\right.$ and day) probably due to level of intake prior to fasting was 2.2 times the maintenance, and in our study was 1.5 times maintenance. But, by other hand, [39] found no differences for fasting HE between ewes of seven breeds differing in potential of production $\left(296 \mathrm{~kJ} / \mathrm{kg}^{0.75} \mathrm{BW}\right.$ and day, on average).

\subsection{Oxidation of Nutrients}

The oxidation of fat was $243 \mathrm{~kJ} / \mathrm{kg}^{0.75} \mathrm{BW}$ on average, and the OXCHO was lower in Guirra than Manchega (72 vs. $129 \mathrm{~kJ} / \mathrm{kg}^{0.75} \mathrm{BW}$, respectively). The oxidation of carbohydrates was $33 \%$ of the $\mathrm{HxE}$ in Manchega and $19 \%$ in Guirra. While the oxidation of fat accounted for 68\% for Guirra and 59\% in Manchega. Although more oxidation of fat is taking place in Guirra than Manchega, no significant differences were found (Figure 2 shows the oxidation of nutrients over time). A trial in Guirraewes [30], found differences in oxidation when different type of carbohydrates on diet were used; a diet with $36 \%$ of barley was replaced by the same amount of fibrous byproduct (soy hulls and gluten feed blend). Different pattern of oxidation was found when diet diets is richer in fiber compared with starch based died; the OXF/HxE was $48 \%$ for the fibrous by-product diet, and the OXCHO/ HxE was $63 \%$ for barley based diet.

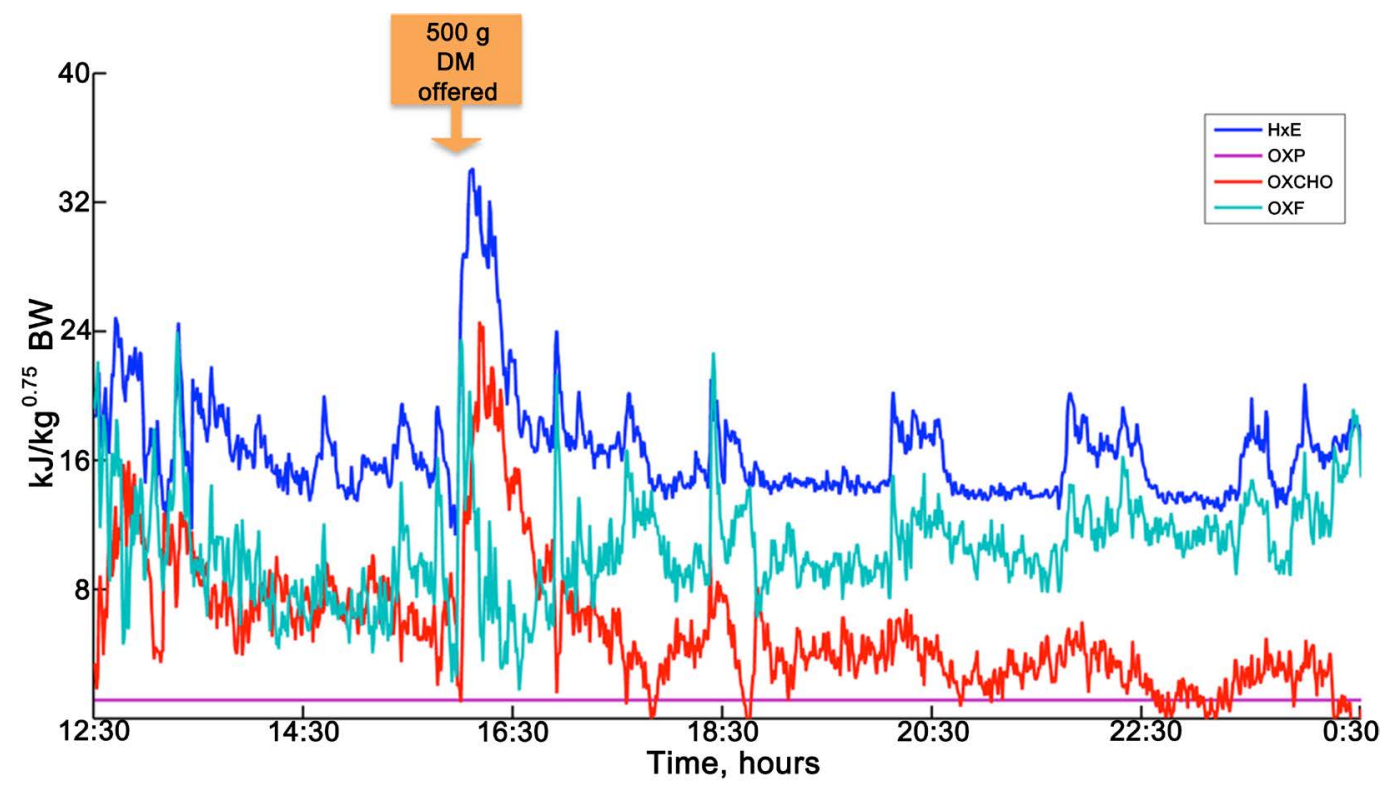

Figure 2. Example of oxidation of nutrients: heat production due to oxidation of nutrients (HxE), oxidation of protein (OXP), oxidation of carbohydrates (OXCHO), and oxidation of fat (OXF). 
However, in this trial the same source of carbohydrate was used in both breeds and, the oxidation of protein in Guirra breed was significantly higher than in Manchega sheep (14\% vs. $7 \%$ OXP/HxE, respectively). In the previous studies, mentioned above, no significant differences were observed between diets and the oxidation of protein was $14 \%$ in Guirra breed [30] and 19\% in Manchega breed [28], so more attention should be necessary in this trial for the nitrogen balance (Table 5) and rumen parameters (Table 6).

\subsection{Nitrogen Balance and Rumen Parameters}

The intake of nitrogen was $1.25 \mathrm{~g} / \mathrm{kg}^{0.75} \mathrm{BW}$ and day on average and, the amount of $\mathrm{N}$ excreted in feces, similar as well $\left(0.33 \mathrm{~g} / \mathrm{kg}^{0.75} \mathrm{BW}\right.$, on average). However, more $\mathrm{N}$ in urine was found in Guirra than Manchega ( 0.65 and $0.35 \mathrm{~g} / \mathrm{kg}^{0.75} \mathrm{BW}$, respectively) and numerical lower retention of protein were found in Guirra (43 vs. $64 \mathrm{~g} / \mathrm{kg}^{0.75}$ BW, respectively). If we observe the ruminal parameters in Table 6, we did not find differences in $\mathrm{pH}$ and profile of VFA, although total amount of VFA was greater in Manchega than Guirra (37.46 vs. $33.49 \mathrm{mmol} / \mathrm{L}$, respectively) and more ammonia $\mathrm{N}$ were found in Guirra compared with Manchega; $22.80 \mathrm{vs.} 17.81 \mathrm{mg} / \mathrm{dL}$, respectively. Breeding differences in urine $\mathrm{N}$ losses was due to lack of efficiency for protein use; greater values of ammonia-N on ruminal liquor. Ruminal ammonia- $\mathrm{N}$ not used for microbial protein synthesis is probably to be excreted in urine [40]. This, associated to the greater OXP and lower OXCHO in Guirra breed, seem indicative of rumen asynchrony between carbohydrates and protein, although we could not identify the cause, more attention should be take to the mature weight.

\section{Conclusion}

The present study demonstrated a tentative approach of partitioning HE, combining indirect calorimetry and integral calculus. The MEm was estimated as $354 \mathrm{~kJ} / \mathrm{kg}^{0.75} \mathrm{BW}$ and day, on average. Differences in basal metabolic rate were found between breeds ( 270 vs. $247 \mathrm{~kJ} / \mathrm{kg}^{0.75} \mathrm{BW}$ for Guirra and Manchega, respectively), and the heat increment of feeding was $14 \%$ of the ME intake. Due to the mature weight of the Guirra breed and the feeding level above maintenance, higher $\mathrm{N}$ in urine and rumen ammonia $\mathrm{N}$ was observed.

\section{Acknowledgements}

This study was supported by the INIA Project (ref. RTA2011-00107-C02-02).

\section{References}

[1] National Research Council (NRC) (1981) Nutritional Energetics of Domestics Animals and Glossary of Energy Terms. National Academy Science Letters, Washintong DC.

[2] Lachica, M., Prieto, C. and Aguilera, J.F. (1997) The Energy of Walking on the Level and on Negative and Positive Slopes in the Granadina Goat (Capra hircus). British Journal of Nutrition, 77, 73-81.

http://dx.doi.org/10.1017/S0007114500002890

[3] Van Klinken, J.B., Van den Berg, S.A.A., Havekes, L.M. and Van Dijk, K.W. (2012) Estimation of Activity Related Energy Expenditure and Resting Metabolic Rate in Freely Moving Mice from Indirect Calorimetry Data. PLoS ONE, 7, e36162. http://dx.doi.org/10.1371/journal.pone.0036162

[4] European Union (EU) (2003) Protection of Animals Used for Experimental Purposes. Council Directive 86/609/EEC of 24 November 1986, Amended 16.9.2003. European Council, Brussels.

[5] Asociación de Criadores de Raza Guirra (ANCRG) (2014) http://www.anguirra.com

[6] Asociación de Criadores de Raza Manchega (AGRAMA) (2014) http://www.agrama.org

[7] Calsamiglia, S., Bach, A., de Blas, C., Fernández, C. and García-Rebollar, P. (2009) Necesidades nutricionales para rumiantes de leche. Fundación Española para el desarrollo de la Nutrición Animal, Madrid.

[8] Fernández, C., López, M.C. and Lachica, M. (2012) Description and Function of a Mobile Open-Circuit Respirometry System to Measure Gas Exchange in Small Ruminants. Animal Feed Science and Technology, 172, 242-246. http://dx.doi.org/10.1016/j.anifeedsci.2012.01.006

[9] McLean, J.A. and Tobin, G. (1987) Animal and Human Calorimetry. Cambridge University Press, Cambridge.

[10] Brockway, J.M., Boyne, A.W. and Gordon, J.G. (1971) Simultaneous Calibration of Gas Analyzers and Meters. Journal of Applied Physiology, 31, 296-297. 
[11] Aguilera, J.F. and Prieto, C. (1986) Description and Function of an Open-Circuit Respiration Plant for Pigs and Small Ruminants and the Techniques Used to Measure Energy Metabolism. Archives of Animal Nutrition, 11, 1009-1018.

[12] Association of Official Analytical Chemists (2000) Official Methods of Analysis.17th Edition, AOAC, Arlington.

[13] Mertens, D.R. (2002) Gravimetric Determination of Amylase-Treated Neutral Detergent Fibre in Feeds with Refluxing Beakers or Crucibles: Collaborative Study. Journal of AOAC International, 85, 1217-1240.

[14] Batey, I.L. (1982) Starch Analysis Using Thermostable Alpha-Amylases. Stach/Stärke, 34, 125-128. http://dx.doi.org/10.1002/star.19820340407

[15] Jouany, J.P. (1982) Volatile Fatty Acid and Alcohol Determination in Digestive Contents, Silage Juices, Bacterial Cultures and Anaerobic Fermentor Contents. Sciences des Aliments, 2, 131-144.

[16] Brouwer, E. (1965) Report of Sub-Committee on Constants and Factors. In: Blaxter, K.L., Ed., Proceedings of the 3 rd Symposium on Energy Metabolism, Academic Press, London, 441-443.

[17] Brouwer, E. (1958) On Simple Formulae for Calculating the Heat Expenditure and the Quantities of Carbohydrate and Fat Metabolized in Ruminants, from Data on Gaseous Exchange and Urine N. In: Proceedings of the 1st Symposium on Energy Metabolism, Academic Press, London, 182-194.

[18] Chwalibog, A., Tauson, A.H. and Thorbek, G. (1997) Quantitative Oxidation of Nutrients in Growing Calves. Zeitschrift für ernährungswissenschaft, 36, 313-316. http://dx.doi.org/10.1007/BF01617806

[19] Fahey, G.C. and Berger, L.L. (1988) Carbohydrate Nutrition of Ruminants. In: Church, D.C., Ed., The Ruminant Animal, Digestive Physiology and Nutrition, Prentice Hall, Englewood Cliff, 269-297.

[20] Agricultural and Food Research Council (AFRC) (1993) Agricultural and Food Research Council. Energy and Protein Requirements of Ruminants. CAB International, Wallingford, UK.

[21] Baldwin, R.L. (1995) Modeling Ruminant Digestion and Metabolism. Chapman and Hall, London, 578 p.

[22] Osuji, P.O., Gordon, J.G. and Webster, A.J.F. (1975) Energy Exchanges Associated with Eating and Rumination of Sheep Given Grass Diets of Different Physical Form. British Journal of Nutrition, 34, 59-71.

[23] SAS, Statistical Analysis System (2001) User's Guide, Version 8.02. Statistical Analysis System Institute Inc., Cary.

[24] Blaxter, K.L. (1967) Techniques in Energy Metabolism Studies and Their Limitations. Proceedings of the Nutrition Society, 26, 86-96. http://dx.doi.org/10.1079/PNS19670016

[25] National Research Council, NRC (2007) Nutrient Requirements of Small Ruminants: Sheep, Goats, Cervids, and New World Camelids. The National Academies Press, Washington DC.

[26] Commonwealth Scientific and Industrial Research Organisation (2007) Nutrients Requirements of Domesticated Ruminants. CSIRO, Collingwood.

[27] Webster, A.J.F. (1983) Chapter 6: Energetic of Maintenance and Growth. In: Girardier, L. and Stock, M., Eds., Mammalian Thermogenesis, Chapman and Hall, London, 178-207. http://dx.doi.org/10.1007/978-94-011-6032-2_6

[28] Fernández, C., López, M.C. and Lachica, M. (2012) Heat Production Determined by the RQ and CN Methods, Fasting Heat Production and Effect of the Energy Intake on Substrates Oxidation of Indigenous Manchega Sheep. Animal Feed Science and Technology, 178, 115-119. http://dx.doi.org/10.1016/j.anifeedsci.2012.09.007

[29] López, M.C. and Fernández, C. (2013) Changes in Heat Production by Sheep of Guirra Breed after Increase in Quantity of Barley Grain on the Diet. Small Ruminant Research, 109, 113-118. http://dx.doi.org/10.1016/j.smallrumres.2012.07.008

[30] López, M.C. and Fernández, C. (2014) Energy Partitioning and Substrate Oxidation by Guirra Ewes Fed Soy Hulls and Corn Gluten Feed Blend as a Replacement for Barley Grain. Animal Feed Science and Technology, 189, 11-18. http://dx.doi.org/10.1016/j.anifeedsci.2013.12.005

[31] Aguilera, J.F., Molina, E., Prieto, C. and Boza, J. (1986) Determination of Energy Requirements for Maintenance in Sheep of Segureña Breed. Archivos de Zootécnia, 35, 89-96.

[32] Kearl, L.C. (1982) Nutrient Requirements of Ruminants in Developing Countries. International Feedstuffs Institute, Utah State University, Logan.

[33] Nsahlai, I.V., Osuji, P.O. and Umunna, N.N. (1997) Digestible Organic Matter Requirements of Ethiopian Menz Sheep: Model and Application. Journal of Applied Animal Research, 11, 83-100. http://dx.doi.org/10.1080/09712119.1997.9706164

[34] Institut National de la Recherche Agronomique, INRA (2007) Alimentation des bovins, ovinsetcaprins. Besoins des animaux. Valeurs des aliments. Tables Inra 2007. Editions Quae, Versailles.

[35] Agricultural and Food Research Council, AFRC (1998) Energy, in Nutrition of Sheep. CAB International, Wallingford, UK, 41-45. 
[36] Blaxter, K.L. (1972) Fasting Metabolism and the Energy Required by Animals for Maintenance. In: Festsdrifttil Knut Breirem, Mariendals Boktryk-keri, Gjovik, 19.

[37] Labussière, E., Dubois, S., Van Milgen, J., Bertrand, G. and Noblet, J. (2008) Fasting Heat Production and Energy Cost of Standing Activity in Veal Calves. British Journal of Nutrition, 100, 1315-1324. http://dx.doi.org/10.1017/S0007114508980648

[38] Taylor, S.C.S. (1985) Use of Genetic Size-Scaling in Evaluation of Animal Growth. Journal of Animal Science, 61, 118-143.

[39] Olthoff, J.C., Dickerson, G.E. and Nienaber, J.A. (1989) Energy Utilization in Mature Ewes from Seven Breeds with Diverse Production Potential. Journal of Animal Science, 67, 2550-2564.

[40] Hoover, W.H. and Stokes, S.R. (1991) Balancing Carbohydrates and Proteins for Optimum Rumen Microbial Yield. Journal Dairy Science, 74, 3630-3644. http://dx.doi.org/10.3168/jds.S0022-0302(91)78553-6 